\title{
CCXLI. FAT METABOLISM OF THE HERRING.
}

\section{A PRELIMINARY SURVEY.}

\author{
By HAROLD JOHN CHANNON AND MOHAMED KAMEL EL SABY. \\ From the Department of Biochemistry, University of Liverpool, and \\ the Marine Biological Station, Port Erin, Isle of Man.
}

(Received October 28th, 1932.)

THE gross chemical changes which occur in the tissues of the herring in different phases of sexual maturity have been studied by a number of workers. Milroy $[1906 ; 1908]$ in a study of the muscles and gonads of Loch Fyne herrings observed a rapid rise in the percentage of fat (ethereal extract of tissue dried at $60-70^{\circ}$ ) in the muscles during the several months prior to the time when rapid growth of ovaries and testes began. This rise was followed by a steady fall and the lowest percentage was reached after the fish had spawned some 3 months later. The percentage of fat in the ovaries was variable. Similar observations were made on fish from the East Coast of Scotland [Milroy, 1907]. In these studies sexual maturity, length and weight of the fish were considered. Johnstone [1920] as a result of successive annual investigations [Johnstone, 1915; 1918; 1919] of the muscle-fat (carbon tetrachloride extract of tissue dried at $100^{\circ}$ for 24 hours) was able to construct curves showing that the fat content of the muscles of Manx herring, which was less than $5 \%$ in May, rose to a maximum in July or August (30-35\%), and then fell rapidly after the fish had spawned. The shape of each curve was characteristic of each season. Bruce [1924] deduced that, at any given stage of sexual maturity, the fat content of herring muscle was increased by age. He also quotes some results of Secker on the amount of fat in the livers and gonads of a number of samples of Clyde herring.

Thus, although much is known of the fat content of various tissues of the herring at different seasons, investigations have hitherto been mainly concerned with the herring as food. They have established irrefutably the progressive rises and falls in the fat content of the edible portion of the fish, but in no case have the investigations been comprehensive enough to allow of deductions being made as to the sequence of changes in fatty constituents occurring in the different tissues of a fish of given age throughout the period of gonad growth.

The work described in this paper was undertaken in an attempt to obtain more exact information regarding the rise and fall in the amount of the fatty constituents of the different tissues from the time when the gonads were 
empty through the various stages of gonad development until the fish had spawned. By studying the amounts of fatty acids and cholesterol of all the tissues throughout the season, it was hoped to throw some light on the processes of translocation of these substances to the gonads.

Apart from the muscle and gonads, therefore, the livers have also been studied. Further, in the herring there is present at certain stages of the season a quantity of fat attached to the outside of the alimentary tract. This "mesenteric" fat has also been included in the investigations and, for ease of description in the Tables, this fat has been described as belonging to the intestine.

$$
\text { Collection of samples. }
$$

Samples of fish were collected once weekly over a period of 14 weeks from June 9 to September 11, 1931, from the marketable catches landed at Port Erin and Peel. From the average catch, something like 60 fish were taken as a sample. From the latter number, after investigation of length, sex and state of maturity, two further samples were taken to represent as far as possible the average of all these factors, each sample consisting of 6 male and 6 female fish. The region from which the fish were taken lies within an area bounded by a line drawn parallel to the west and south-west coasts of the Isle of Man between Peel and Port St Mary, and 8 to 10 miles from the coast, which constitutes the Port Erin fishing ground.

Observations of length, sex, state of maturity of roe or milt on Hjort's scale, and age were made on each fish of every sample. The number of vertebrae in the whole samples (about 1600 fish) were counted. These results are published separately [Saby, 1932]. Length was measured from the snout tip to the end of the longest caudal fin ray in the dorsal fluke of the tail.

The degree of maturity was classified on Hjort's scale. The classes actually encountered were: I, virgin, II, maturing virgins or recovering spents; III, gonads filling one-half the body cavity; IV, gonads filling more than two-thirds of the cavity; V, full; gonads filling the body cavity; VII, spent.

For the determination of age, several scales from the anterior region near the tip of the pectoral fin were removed and dried in air. Each collection was preserved in a numbered envelope, and later the scales were cleared and the winter rings counted under a binocular microscope according to the method of Lea [1910].

After determination of its weight, each fish was carefully dissected, and the liver, gonad and alimentary canal and a portion of the muscle were removed. The livers and gonads were readily obtained, but it was not found possible to remove the alimentary tract without some loss of the adherent fat. The alimentary tract was severed at the oesophagus and taken out entirely. The stomach was then opened and cleared, and gentle pressure was applied to the intestine in order to squeeze out as much of the remaining food residues as possible. The muscle sample was taken by cutting a fillet of the edible flesh extending from just behind the pectoral fin to the tail region. The selected tissues were then stored in stoppered bottles under excess of acetone until the collection was completed (14 weeks), when they were brought to Liverpool and worked up during the following 8 months. Each week there were thus obtained bottles containing respectively the livers, gonads, alimentary tracts and muscle fillets from 6 male fish, and the corresponding samples from 6 female fish. Table I gives the data concerning all the samples.

\section{The determination of fatty acids and the unsaponifiable fraction.}

Because of the labour and expense involved, it was decided in the first place to work up the samples from alternate weeks; the results obtained were so definite as to make it unnecessary to investigate the remainder.

The acetone was removed from each sample by filtration and the residue was repeatedly warmed with fresh samples of acetone, filtration and grinding of the residue in a mortar following each extraction. The combined acetone filtrates were evaporated to dryness in vacuo. The dry powdered residue was then extracted with ether (Soxhlet, 8 hours). The ethereal extract was added to the residue from the acetone, and the whole evaporated to dryness. The residue obtained 


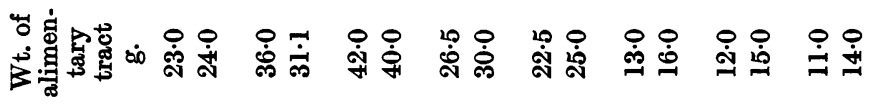

苍范范

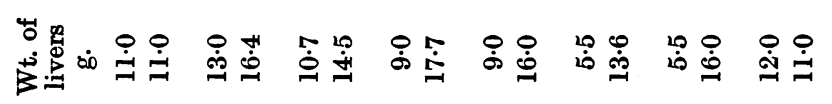

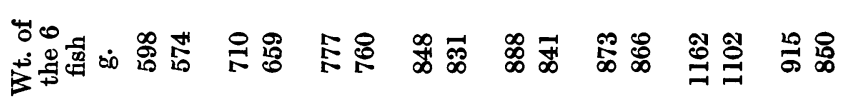

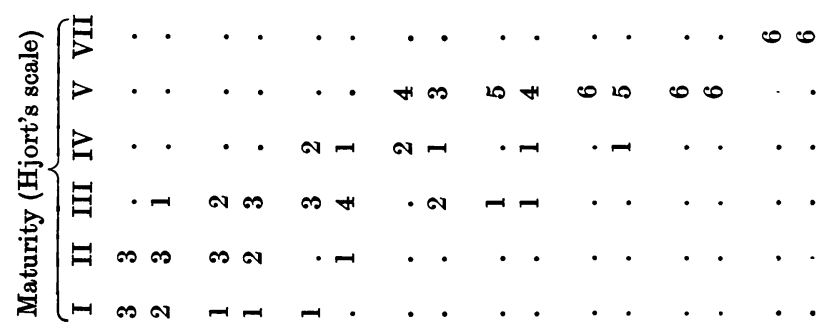

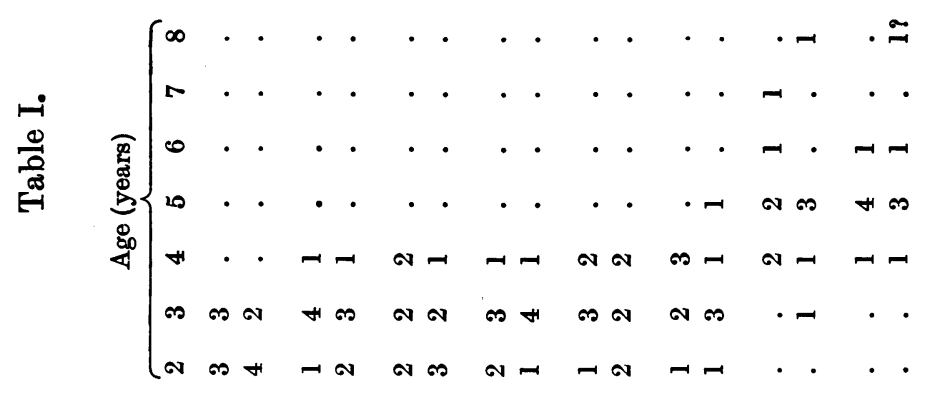

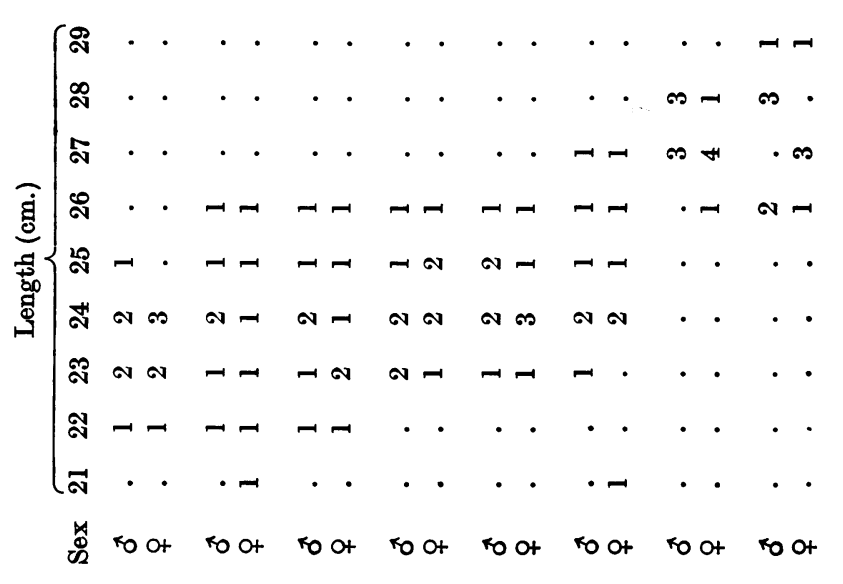

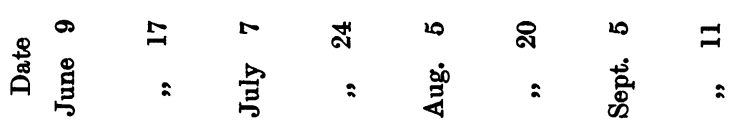


was then saponified by boiling with excess of alcoholic potassium hydroxide and, after removal of much of the alcohol, followed by dilution with water, the unsaponifiable fraction was obtained by 6 extractions with ether. The ethereal extract, after washing with water to neutrality, yielded, on evaporation and drying in vacuo at $100^{\circ}$, the unsaponifiable fraction. The combined soap solutions and aqueous washings were acidified with hydrochloric acid, and similarly extracted with ether. After washing, the ethereal extract was evaporated and the residue dried at $100^{\circ}$ in vacuo. It was then dissolved in light petroleum and allowed to stand overnight. After filtration, the light petroleum solution yielded, on evaporation, the fatty acids, which were dried at $100^{\circ}$ in vacuo and weighed. Iodine values [Rosenmund and Kuhnhenn, 1923] were determined on the fatty acids and unsaponifiable fraction, and the amount of cholesterol in the latter by the digitonin method.

\section{Results.}

The percentage yield of fatty acids.

The yields of fatty acids (g. per $100 \mathrm{~g}$. of fresh tissue) are recorded in Table II.

Table II. Percentage yield of fatty acids.

\begin{tabular}{|c|c|c|c|c|c|c|c|c|}
\hline \multirow[b]{2}{*}{ Date } & \multicolumn{2}{|c|}{ Liver } & \multicolumn{2}{|c|}{ Intestine } & \multicolumn{2}{|c|}{ Muscle } & \multicolumn{2}{|c|}{ Gonad } \\
\hline & $\sigma^{*}$ & q & o & q & ot & o & a & 우 \\
\hline $\begin{array}{l}\text { June } 17 \\
\text { July } 7\end{array}$ & $\begin{array}{l}11 \cdot 43 \\
14.48\end{array}$ & $\begin{array}{l}10 \cdot 76 \\
15 \cdot 47\end{array}$ & $\begin{array}{l}30 \cdot 85 \\
40 \cdot 34\end{array}$ & $\begin{array}{l}22 \cdot 32 \\
38 \cdot 30\end{array}$ & $\begin{array}{l}10.00 \\
13.71\end{array}$ & $\begin{array}{l}10 \cdot 66 \\
17 \cdot 19\end{array}$ & $\begin{array}{l}5 \cdot 14 \\
5 \cdot 64\end{array}$ & $\begin{array}{l}2 \cdot 61 \\
4 \cdot 79\end{array}$ \\
\hline \# 24 & $9 \cdot 31$ & 8.83 & $31 \cdot 93$ & 28.99 & 17.83 & 17.09 & 1.82 & 3.84 \\
\hline Aug. 5 & $13 \cdot 12$ & 10.92 & 23.59 & $21 \cdot 10$ & 17.54 & $14 \cdot 58$ & 1.58 & $4 \cdot 35$ \\
\hline & $5 \cdot 13$ & $5 \cdot 77$ & $10 \cdot 63$ & $15 \cdot 31$ & $15 \cdot 09$ & $16 \cdot 04$ & 1.90 & $3 \cdot 16$ \\
\hline Sept. 5 & 2.59 & 3.92 & $1 \cdot 47$ & $2 \cdot 85$ & $12 \cdot 73$ & $14 \cdot 24$ & $2 \cdot 12$ & $4 \cdot 15$ \\
\hline 11 & 0.99 & 1.29 & 0.87 & $1 \cdot 26$ & $10 \cdot 86$ & Lost & Spent & Spen \\
\hline
\end{tabular}

These figures show that in the 21 days between June 17 and July 7 there has been a very large increase in the percentage of fatty acids in the liver, intestine and muscle. The percentage increases over the values of June 17

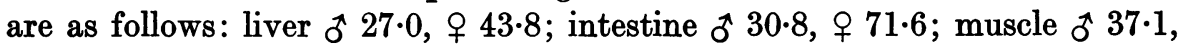
o $61 \cdot 3$. In the liver and intestine, both for male and female fish, July 7 marks the highest values obtained throughout the experiment. From this date onwards there is a steady decrease throughout the remainder of the period. Thus, in the last samples, the spent fish of September 11, the percentage of fatty acid in the livers has sunk to 0.99 and 1.29 for the males and females respectively, as against 14.48 and $15.47 \%$ on July 7 , showing that just over $90 \%$ of the initial liver-fatty acids have been utilised or translocated elsewhere. The results with the intestinal fat are even more striking, for the fatty acids disappearing account for 97.9 and $96.7 \%$ of those present on that date. The maximum percentage of fatty acids in the muscle appears to occur rather later, July 24, and the final percentage in the last sample in the male fish shows a fall of $39 \%$ from the highest value. The final female sample was unfortunately lost; but the value for the previous collection of September 5 shows a fall of $17 \cdot 2 \%$. The percentage fatty acid content of the gonads in the different samples shows no regular change, which is perhaps a somewhat unexpected result, although similar to that of Milroy [1908].

The results are expressed graphically in Fig. 1 where the marked initial rises in the percentage fatty acids of liver, intestine and muscle are clearly 
seen, as are the gradual progressive losses of fatty acids from these tissues with gonad development. The approximately $70 \%$ increase in the percentage of muscle-fatty acids in the first 38 days is noteworthy. (It is to be observed that in Fig. 1 the curves are all drawn on the same scale save those for the intestinal fat which, reaching a percentage of 40 and falling finally to about $1 \%$, necessitates a scale one-fifth as great.)

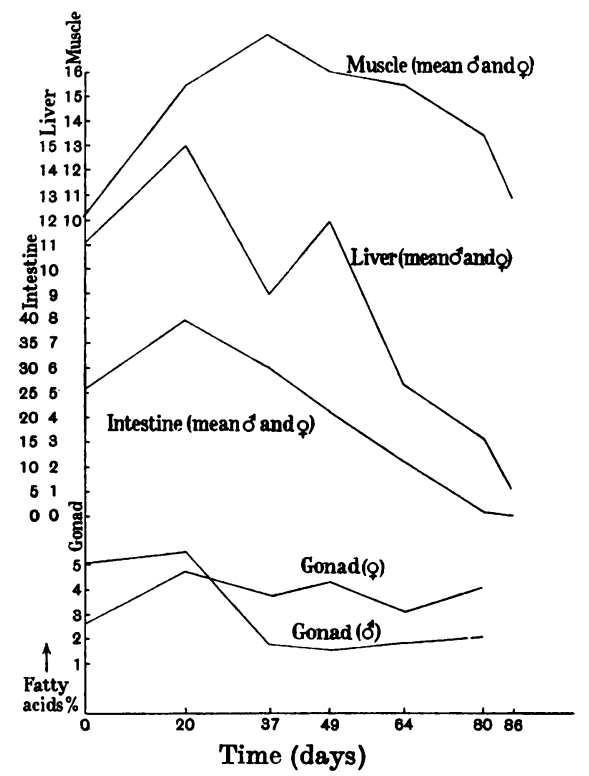

Fig. 1. Variation in the percentage of fatty acids in the tissues of the herring during the maturation period.

The percentage yield of unsaponifiable matter.

The yields of unsaponifiable matter (g. per $100 \mathrm{~g}$. of fresh tissue) are recorded in Table III.

Table III.

\begin{tabular}{|c|c|c|c|c|c|c|c|c|}
\hline \multirow[b]{2}{*}{ Date } & \multicolumn{2}{|c|}{ Liver } & \multicolumn{2}{|c|}{ Intestine } & \multicolumn{2}{|c|}{ Muscle } & \multicolumn{2}{|c|}{ Gonad } \\
\hline & t & 웅 & t & क & व & 우 & के & 우 \\
\hline June 17 & 1.09 & 0.81 & 0.54 & 0.61 & $0 \cdot 19$ & 0.19 & 0.43 & 0.47 \\
\hline July 7 & 1.04 & 0.94 & 0.58 & 0.61 & $0 \cdot 15$ & $0 \cdot 15$ & 0.63 & 0.52 \\
\hline,$\quad 24$ & $1 \cdot 11$ & 0.72 & $0 \cdot 76$ & $0 \cdot 65$ & 0.15 & 0.22 & 0.38 & 0.58 \\
\hline Aug. 5 & $1 \cdot 13$ & 0.67 & 0.60 & 0.45 & $0 \cdot 17$ & 0.18 & 0.45 & 0.54 \\
\hline, 20 & 0.72 & 0.49 & 0.71 & 0.67 & $0 \cdot 19$ & 0.22 & 0.60 & 0.47 \\
\hline Sept. 5 & $1 \cdot 40$ & 0.41 & 0.92 & 0.66 & 0.13 & $0 \cdot 16$ & 0.66 & 0.51 \\
\hline 11 & 0.31 & 0.46 & $0 \cdot 37$ & 0.48 & 0.15 & - & Spent & Spen \\
\hline
\end{tabular}

In Table IV the unsaponifiable matter is expressed as a percentage of the fatty acids. The unsaponifiable fractions consist largely of cholesterol, the average figures being liver $42 \%$, intestine $57 \%$, muscle $37 \%$, gonad $84.5 \%$. 


\begin{tabular}{|c|c|c|c|c|c|c|c|c|}
\hline \multirow[b]{3}{*}{ Date } & \multicolumn{6}{|c|}{ Table IV. } & & \\
\hline & \multicolumn{2}{|c|}{ Liver } & \multicolumn{2}{|c|}{ Intestine } & \multicolumn{2}{|c|}{ Muscle } & \multicolumn{2}{|c|}{ Gonad } \\
\hline & శే & 우 & శే & 우 & o & 우 & ot & 우 \\
\hline June 17 & $9 \cdot 6$ & $7 \cdot 5$ & $1 \cdot 75$ & $2 \cdot 74$ & 1.9 & $1 \cdot 78$ & $8 \cdot 3$ & $18 \cdot 0$ \\
\hline July 7 & $7 \cdot 2$ & $6 \cdot 1$ & 1.44 & 1.59 & 1.09 & $0 \cdot 87$ & $11 \cdot 2$ & $10 \cdot 9$ \\
\hline ,, 24 & 11.9 & $8 \cdot 2$ & $2 \cdot 38$ & $2 \cdot 24$ & 0.84 & $1 \cdot 29$ & 20.9 & $15 \cdot 1$ \\
\hline Äug. 5 & $8 \cdot 6$ & $6 \cdot 1$ & $2 \cdot 54$ & $2 \cdot 13$ & 0.97 & 1.23 & $28 \cdot 5$ & $12 \cdot 4$ \\
\hline ,, 20 & $14 \cdot 0$ & $8 \cdot 7$ & $6 \cdot 68$ & $4 \cdot 37$ & $1 \cdot 26$ & $1 \cdot 37$ & $31 \cdot 6$ & 14.9 \\
\hline Sept. 5 & $54 \cdot 0$ & $10 \cdot 5$ & $62 \cdot 60$ & $23 \cdot 12$ & 1.02 & $1 \cdot 14$ & $31 \cdot 1$ & $12 \cdot 3$ \\
\hline , 11 & $31 \cdot 3$ & $35 \cdot 7$ & $42 \cdot 53$ & 38.09 & $1 \cdot 38$ & - & Spent & Spent \\
\hline
\end{tabular}

From the figures recorded in Table IV it is clear that the rate of utilisation of the unsaponifiable fractions is very much less rapid than that of the fatty acids of the liver and intestine, which Table II shows are almost completely lost from those tissues by the time that maturation is complete. Thus, whereas in the liver on June 17 the percentage of unsaponifiable matter is about $1 / 12$ that of the fatty acids, on September 11 it constitutes about 1/3, a fourfold increase. Similarly for the intestine, the ratio of unsaponifiable matter to fatty acids rises from its initial value to a final one something like 20 times as great. The high ratio in the gonads is to be expected, while the lack of regularity in these figures is consequent upon the variable percentages of fatty acids in the different samples, as recorded in Table II.

\section{The iodine values of the fatty acids.}

It is not necessary to reproduce the iodine values in full, because, save in the case of the gonads, the variations obtained were irregular and no deductions could be made from them. The extreme and mean values are recorded in Table $\mathrm{V}$.

Table V. Variations in iodine values of the fatty acids.

\begin{tabular}{|c|c|c|c|c|c|c|}
\hline & & & & & M & \\
\hline & ot & 우 & $\sigma^{1}$ & 우 & $\sigma^{\prime}$ & 우 \\
\hline Liver & 133 & 141 & 120 & 115 & 127 & 130 \\
\hline Intestine & 124 & 122 & 91 & 91 & 107 & 109 \\
\hline Muscle & 136 & 126 & 102 & 105 & 116 & 119 \\
\hline
\end{tabular}

In the case of the gonads, however, the fatty acids showed a progressive increase in unsaturation with the development of maturity, and these figures are presented in Table VI.

Table VI. Iodine values of fatty acids of gonads.

\begin{tabular}{cccccccc} 
& June 17 & July 7 & July 24 & Aug. 5 & Aug. 20 & Sept. 5 & Sept. 11 \\
\multirow{0}{*}{} & 128 & 151 & 162 & 158 & 195 & 209 & Spent \\
$\$$ & 146 & 143 & 163 & 170 & 174 & 195 & $\#$
\end{tabular}

The high degree of unsaturation of the fatty acids just before spawning is noteworthy, as is also the fact that these fatty acids are very much more unsaturated than even those of the liver itself. 
Superficially, the fact that the gonad-fatty acids have iodine values some $50 \%$ greater than the fatty acids of any of the other tissues suggests that desaturation of the fatty acids is occurring, especially as for the last month at least the fish is not feeding. Alternatively, the high degree of unsaturation of the gonad-fatty acids might be due to preferential translocation of the more unsaturated acids from the liver. The first point to be mentioned, as will be shown later, is that at the time of maturation the gonads contain about $1 \mathrm{~g}$. of total fatty acid, whereas the liver has a maximum fatty acid content of only about $0.3 \mathrm{~g}$. which falls to about $20 \mathrm{mg}$. when maturation is complete. Since the iodine value of the liver-acids does not change significantly during the maturation period, and further, since the total loss of fatty acid from the liver is no more than $0.28 \mathrm{~g}$., it is clear that the fatty acids which the liver has lost cannot in any way explain the presence in the gonad of $1 \mathrm{~g}$. of fatty acid of iodine value 200 . On the other hand, preferential transference of the more unsaturated acids from the muscle to the gonad could account for the high iodine value of the gonad-fatty acids, for the muscle of the average fish contains about $17 \mathrm{~g}$. of fatty acids during the earlier period, of which about $4 \mathrm{~g}$. are lost by the time that maturation is complete. These $4 \mathrm{~g}$. of iodine value 116 would provide 464 available iodine units, of which the $1 \mathrm{~g}$. of fatty acids in the gonads at maturity require only 200 . Hence the loss of fatty acids from the muscle could account for the appearance of $1 \mathrm{~g}$. of fatty acids of iodine value 200 in the ripe gonad, without the iodine value of the remaining muscle-fatty acids changing. Similar reasoning can be applied to the fatty acids of the intestinal fat. During the later stages of the maturation period the fish is calling on its reserves of fat for energy purposes. If the more unsaturated acids disappearing were translocated to the gonads and only the more saturated acids were being burnt, then results recorded in Table VI would be explained without invoking the aid of a desaturation hypothesis. On the other hand, it is possible that the gonad-fatty acids may represent the results of a desaturation process occurring in the liver or elsewhere, and evidence on this question is now being sought. Further, the possibility of a synthesis in situ must not be overlooked. The occurrence of these acids of high iodine value in the ovaries and testes may suggest that they are present as phosphatides, which the findings of Milroy $[1906 ; 1908]$ and Bruce [1924] of an increasing phosphorus content in these tissues with maturation may imply.

\section{Yield of sterol.}

Cholesterol was not estimated in the unsaponifiable fractions until the samples of July 24. These are set out in Table VII. These figures show a regular decrease in the percentage of liver-cholesterol, while that of the muscle remains constant. The figures for the cholesterol content of the intestine are somewhat irregular.

On the other hand the contrasting results for the testes and ovaries are 
worthy of mention. Whereas in the testes the amount of cholesterol is steadily increasing to a maximum prior to the spawning of the fish that of the ovaries shows but small and irregular changes with the approach of maturity.

Table VII. Yield of sterol per $100 \mathrm{~g}$. of fresh tissue (mg.).

\begin{tabular}{|c|c|c|c|c|c|c|c|c|}
\hline \multirow[b]{2}{*}{ Date } & \multicolumn{2}{|c|}{ Liver } & \multicolumn{2}{|c|}{ Intestine } & \multicolumn{2}{|c|}{ Muscle } & \multicolumn{2}{|c|}{ Gonad } \\
\hline & ot & $q$ & $\sigma^{\pi}$ & q & $\sigma^{2}$ & q & o & q \\
\hline July 24 & $\overline{550}$ & 431 & 294 & 338 & 67 & 75 & 335 & 458 \\
\hline Aug. $\begin{array}{r}5 \\
20\end{array}$ & $\begin{array}{l}\mathbf{5 5 9} \\
\mathbf{3 7 5}\end{array}$ & 366 & 316 & 351 & 68 & 65 & 369 & 438 \\
\hline Sept. ${ }^{20}$ & $\begin{array}{l}375 \\
263\end{array}$ & 187 & 492 & $\begin{array}{l}318 \\
297\end{array}$ & 64 & $\begin{array}{l}69 \\
66\end{array}$ & $\begin{array}{l}533 \\
615\end{array}$ & $\begin{array}{l}397 \\
410\end{array}$ \\
\hline$" 11$ & 168 & 197 & 244 & - & 66 & - & Spent & Spent \\
\hline
\end{tabular}

The absolute gains and losses of fatty acids and cholesterol by the tissues.

With tissues which are increasing or decreasing so rapidly in weight (gonad, liver, intestine), the expression of the fatty constituents as percentage figures gives no idea of the changes in weight which these constituents undergo. It is of considerable interest therefore to attempt to convert these percentage figures into weights, in order to gain some idea of the magnitude of the loss or gain of the fatty constituents by the various tissues in the successive stages of maturation. This raises the question as to whether it is safe to assume for the purposes of discussion of the results that fish drawn from one fishing ground over a limited time, if comparable as regards age and sexual maturity, may be regarded within rough limits as comparable in other respects, provided the inherent error of small random sampling be adequately recognised at the outset. It is of course definitely known that herring spawn at definite and often widely differing times in different latitudes. Thus herring in the Port Erin area always spawn in August and September, while in Western Scottish waters the period is January and February [Milroy, 1908], and other examples may be cited. Unless therefore the herring caught in a given area consist of a number of different races, in which the weight to age ratio varies considerably, it appears to us that it may not be unprofitable to compare the weights of the fatty constituents present in successive samples and to consider the changes in these weights as roughly representing the results of the metabolism during the intervening periods, provided the ages of the fish and the degree of sexual maturity which are known are comparable. (The results of counting the vertebrae of the 1600 fish from which our samples were drawn provide no evidence for the existence of different races [Saby, 1932].)

Fourteen samples in all were analysed over the period June 17 to September 11, each sample consisting of 6 fish, and we may now consider the ages of the fish constituting the different samples. It is seen (Table I) that in every one of the 10 samples from June 17 to August 20 there are present one 2-year old, two 3-year old and one 4-year old fish, i.e. in each sample 4 of the 6 fish are of the same age. Of the 60 fish, therefore, 40 are equally distributed as regards age in the 10 samples. Further, save for one 
individual fish, the remaining 20 are also 2,3 or 4 years old. We may take it also that any 3-year old fish in these 20 should play no part in rendering the weight relations incomparable. Of these there are 8 . Hence it seems to us that of the 60 fish in the 10 samples only 12 should cause any possible serious variation in weight relationships. Further, in two samples there are two 2-year old fish, but these are offset by the presence of two 4-year old fish, and these samples also should therefore be comparable with the rest. Thus, of the 60 fish involved in these 10 samples, only 8 should cause any appreciable variation and, remembering that the difference in size of 2, 3 and 4-year old herring is not large, it seems to us that these 10 samples may be compared as a rough approximation. Further, the average length of the 6 fish in each of these 10 samples is $24,23 \cdot 5 ; 24 \cdot 0,23 \cdot 8 ; 24 \cdot 2,24 \cdot 5 ; 24 \cdot 5,24 \cdot 3 ; 24.8$ and $24 \cdot 7 \mathrm{~cm}$. over 65 days. This appears to confirm the reasoning regarding the even distribution as regards ages, and strengthens the ground for regarding the weight of fatty acids in the tissues of the fish of various successive samples as representing actual metabolic changes occurring between successive samplings. These samples are also in order of increasing maturity (Table I).

On the other hand, the last four samples of September 5 and 11 are not comparable with these 10 , because, of the 24 fish involved, 18 are over 4 years old. The average ages of these samples are $5 \cdot 3,5 \cdot 0,6 \cdot 0$ and $5 \cdot 2$ years, and their average lengths $27 \cdot 5,27 \cdot 5,27 \cdot 5$ and $27 \cdot 3 \mathrm{~cm}$., whereas the extremes in the average length of the fish in each of the first 14 samples are 23.5 and $24.8 \mathrm{~cm}$.

Although the weights on September 5 and 11 are thus vitiated it is of some importance to derive figures for these two dates, especially for September 5, which was the last day on which the fish were taken before spawning, and we think that a close approximation can be obtained.

Before proceeding to discuss this matter further it is to be pointed out that only fillets of the muscle were taken and hence the total muscles of each fish were not weighed at the time of collection, but the approximate weights of the muscles can be derived from Table I. In order to obtain a figure for the muscles of the herring, 8 fish of markedly varying weights and gonad development were dissected and the alimentary tracts, livers and gonads removed. The residue, consisting of muscle, head, tail and skeleton was weighed, W. The muscle was then torn away and the head cut off. The combined weight of the head and tail and the skeleton after washing in water and roughly drying represented $17 \cdot 6$ to $21 \cdot 3 \%$ of W. For the purposes of this discussion, therefore, the total weight of muscle may be taken as $80 \%$ of the weight of the total fish less that of the alimentary tract, liver and gonad. Using this figure of $80 \%$, therefore, the figures on p. 2030 are thus derived from Table I.

The big increases in the muscle weight of the samples of September 5 and 11 are at once apparent.

We incline to the view that the percentage composition of fish in the same stage of maturity does not vary significantly with age. It is true that Bruce 


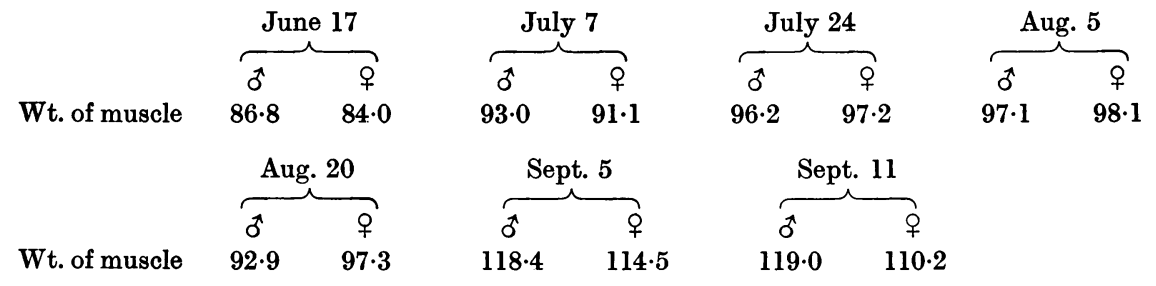

[1924] deduces from his muscle analyses that the fat content of the muscle at any given gonad stage depends to some extent on age, but from the present work it is clear that any slight difference due to age is insignificant relatively to the influence of different states of sexual maturity. Now the muscles of the 6 samples preceding September 5 approximate in a sufficiently constant manner to $97 \mathrm{~g}$. to make it accurate for our purposes for this weight to be taken for the samples of September 5 and 11. In Table VIII and Fig. 2 which follow, therefore, the total muscle-fatty constituents for these two dates has been derived by multiplying the found percentages not by the known weights but by the deduced figure 97 .

No similar correction need be applied to the liver and intestine, for at this stage their respective weights are only about $2 \mathrm{~g}$. and they contain only about $1 \%$ of fat.

The last gonad weights, however, of September 5 are naturally in need of correction. Since this tissue is increasing in weight rapidly at this time, it is an uncertain proceeding to attempt to correct it, and therefore in the Tables which follow the figures for the gonads of September 5 appear in brackets, and the last portion of the curve is shown as a broken line.

It is of interest to note in passing that the weights of fatty acids in the gonads plotted against time lie on a straight line up to the date preceding September 5. If this straight line were continued to give a corrected figure for the value under discussion we obtain $0.66 \mathrm{~g}$. as against the $1.18 \mathrm{~g}$. given by the enhanced finding on the actual weight of the older fish. That this figure $(0.66 \mathrm{~g}$.) must be significantly low is shown by the cholesterol figures in Table IX. Reduction of the sterol figure of September 5 proportionately results in a sterol figure for the September 5 samples actually below that of August 20. This means that, if cholesterol and fatty acids are increasing at the same rate, the fatty acid figure must be considerably greater than $0 \cdot 66 \mathrm{~g}$.

There are now presented tables showing the variation in the weights of the fatty acids in the different tissues of the average fish.

The figures in Table VIII may therefore be taken as an approximate indication of the changes which occur in a 3-year old herring during the period of active growth of the gonads from an initial weight of $0.8 \mathrm{~g}$. to a final weight of $39 \mathrm{~g}$. when spawning occurs. The liver-fatty acids increase during the first 3 weeks from an initial value of $0.27 \mathrm{~g}$. to the slightly higher figure of $0.31 \mathrm{~g}$. For the remainder of the period, the liver steadily loses its fatty acids until in the week after spawning not more than $20 \mathrm{mg}$. remain. The intestinal fat 
Table VIII. Total weight of fatty acids in the different tissues

of the average fish $(\mathrm{g}$.$) .$

\begin{tabular}{|c|c|c|c|c|c|c|c|c|}
\hline \multirow[b]{2}{*}{ Date } & \multicolumn{2}{|c|}{ Liver } & \multicolumn{2}{|c|}{ Intestine } & \multicolumn{2}{|c|}{ Muscle } & \multicolumn{2}{|c|}{ Gonad } \\
\hline & $\pi$ & 우 & $\sigma^{\pi}$ & 우 & o & 우 & o & 우 \\
\hline June 17 & 0.26 & 0.29 & 1.85 & $1 \cdot 16$ & $8 \cdot 68$ & 8.95 & 0.09 & 0.07 \\
\hline July 7 & $0 \cdot 26$ & $0 \cdot 37$ & $2 \cdot 82$ & $2 \cdot 57$ & $12 \cdot 75$ & $15 \cdot 66$ & $0 \cdot 26$ & $0 \cdot 18$ \\
\hline ,, 24 & $0 \cdot 14$ & 0.26 & $1 \cdot 40$ & 1.45 & $17 \cdot 16$ & $16 \cdot 61$ & $0 \cdot 27$ & $0 \cdot 36$ \\
\hline Aug. 5 & 0.20 & 0.29 & 0.87 & 0.89 & 17.03 & $14 \cdot 31$ & 0.33 & 0.46 \\
\hline , 20 & 0.05 & 0.13 & 0.23 & 0.41 & 14.02 & 15.62 & 0.50 & 0.56 \\
\hline Sept. 5 & $0 \cdot 02$ & $0 \cdot 10$ & $0 \cdot 03$ & 0.08 & $12 \cdot 35^{*}$ & $13 \cdot 82^{*}$ & $(0.90)$ & $(1 \cdot 47)$ \\
\hline , $\quad 11$ & 0.02 & 0.02 & 0.02 & 0.03 & $10 \cdot 54^{*}$ & Lost & - & 一 \\
\hline
\end{tabular}

increases similarly in the first 21 days to $2 \cdot 7 \mathrm{~g}$. and the whole of this amount is then steadily lost by the time that spawning occurs. The fatty acids of the muscle, $8.8 \mathrm{~g}$., however, regularly increase for a rather longer time (about 5 weeks) and thus reach their maximum towards the half-way stage of the maturation process at $16.8 \mathrm{~g}$. They then undergo a roughly similar rate of decrease to a weight of about $10.5 \mathrm{~g}$. in the 13th week. Meanwhile the gonadfatty acids commencing at $80 \mathrm{mg}$. increase steadily to a maximum prior to spawning. These rises and falls are illustrated in Fig. 2.

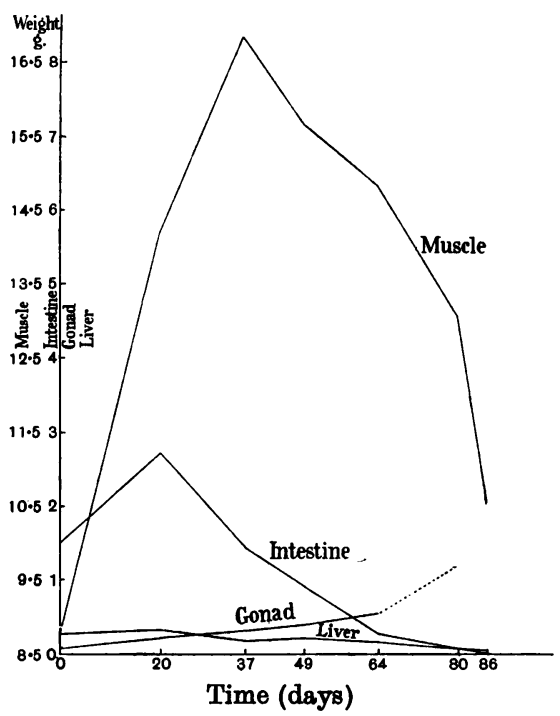

Fig. 2. Variation in weight of fatty acids in the tissues of the average fish during the maturation period (mean $\delta^{\pi}$ and + ).

It is not possible to deduce the source of the gonad-fatty acids. It is perhaps of importance to observe that the fatty acids of the liver and mesentery have begun to decrease after 21 days although the muscle-fatty acids are rapidly increasing in the male fish and slightly in the female. This is the more striking when it is remembered that the increase in the muscle-fatty acids 
during the next 17 days in the male is $4.4 \mathrm{~g}$., and yet during this time the intestine has lost $1.4 \mathrm{~g}$., and even the very small initial amount of fatty acid in the liver, $0.27 \mathrm{~g}$., is tending to fall. It appears as though the intestinal fatty acids were serving as reserve fat for increasing the muscle-fat as required, but it is not easy to see why fat deposited as reserve fat should be mobilised in order to increase that of the muscles, unless the muscles were possibly playing some part in the preparation of those fatty acids for use possibly by the gonads. It is to be noted that no food was found in the fishes' alimentary tracts after the beginning of August, i.e. when the intestinal fat has begun rapidly to decrease. Equally curious also is the fact that the liver containing only $0.27 \mathrm{~g}$. of fatty acid should lose the greater part of this small amount when such relatively vast quantities are available in the muscle.

The losses and gains of the tissues from the time of maximum fatty acid content to September 11 are as follows:

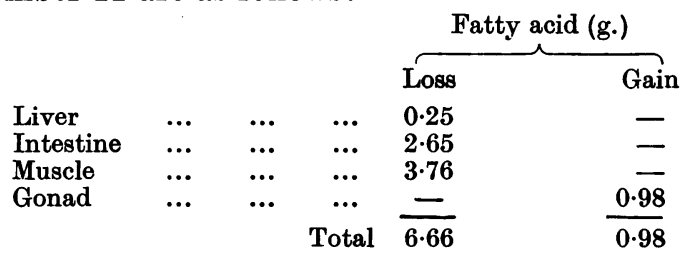

The net loss of $5 \cdot 68 \mathrm{~g}$. must have gone towards the supply of energy during the final period of abstention from food.

\section{Table IX. Total weight of cholesterol in the different tissues} of the average fish (mg.).

\begin{tabular}{|c|c|c|c|c|c|c|c|c|}
\hline \multirow[b]{2}{*}{ Date } & \multicolumn{2}{|c|}{ Liver } & \multicolumn{2}{|c|}{ Intestine } & \multicolumn{2}{|c|}{ Muscle } & \multicolumn{2}{|c|}{ Gonad } \\
\hline & $\vec{a}$ & q & $\sigma^{t}$ & क & d & के & $\sigma^{x}$ & 우 \\
\hline July 24 & - & $12 \cdot 7$ & 12.9 & 16.9 & $64 \cdot 5$ & $72 \cdot 9$ & 51 & 43 \\
\hline Aug. 5 & $8 \cdot 4$ & $9 \cdot 9$ & 11.7 & $14 \cdot 7$ & 66.0 & $63 \cdot 8$ & 79 & 46 \\
\hline Sept. 20 & $\begin{array}{l}\begin{array}{l}3.3 \\
2 \cdot 4\end{array} \\
\text {. }\end{array}$ & $\begin{array}{l}5 \cdot 9 \\
5.0\end{array}$ & $\overline{9 \cdot 8}$ & $\begin{array}{l}8.5 \\
7.4\end{array}$ & $59 \cdot 5$ & $64.0 *$ & 140 & $\begin{array}{c}70 \\
(145)\end{array}$ \\
\hline , 11 & $3 \cdot 4$ & $3 \cdot 5$ & $4 \cdot 4$ & - & $64 \cdot 0^{*}$ & - & Spent & Spent \\
\hline
\end{tabular}

From the figures in Table IX it is seen that there is a steady loss of cholesterol from the liver and intestine, and a rapid gain by the gonad of that substance, while the figure for the muscle remains constant. Further, at every stage of maturation the milt contains considerably more cholesterol than the roe.

It seems to us that these figures provide evidence that the fish is synthesising cholesterol. In view of the uncertainty which exists as to the last figure for the gonad-cholesterol on September 5, as discussed on p. 2030, it may be wise to consider that of August 20, which must be very considerably less than the true value for September 5. In the period July 24-August 20 the gonads have gained $56 \mathrm{mg}$. of cholesterol. In the same period the liver on 
the average has lost about $9 \mathrm{mg}$. and the intestine $6.3 \mathrm{mg}$., a total of about $15 \mathrm{mg}$. Bearing in mind the fact that the fish is not feeding at this time, this suggests a synthesis of cholesterol by the herring of about $40 \mathrm{mg}$. in 6 weeks. The possibility that there had been some mobilisation of sterol from the heads of the fish was not investigated at the time, but has been determined since on heads of fish taken in September 1932. The heads of 8 mature and 8 spent 5-year old fish, for the collection of which we wish to thank Mr W. C. Smith, were saponified in the usual manner and the unsaponifiable fraction was prepared, and the amount of cholesterol present determined. The average figures for the heads of these fish were as follows:

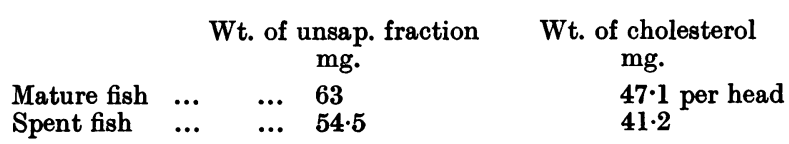

The differences between the figures for the mature and spent fish are insignificant, and hence we incline to the view that the fish is synthesising sterol during the later stages at least of the maturation period.

\section{SUMMARY.}

1. A quantitative study has been made of the fatty acids and cholesterol in the different tissues of the Manx herring from the time when the gonads are empty, through the stages of complete maturation to the spawning of the fish about 12 weeks later. Age, weight, length and sex have been considered.

2. The percentages of fatty acids in the liver and "mesentery" increase for 3 weeks to a maximum (15 and $39 \%$ respectively) and then fall to about $1 \%$ by the time of spawning. The maximum in the muscles, $17 \cdot 4 \%$, occurs rather later (about 5 weeks) and then progressively falls, approaching the initial value. Meanwhile the rapidly growing ovaries and testes show varying percentages throughout.

3. The percentage of cholesterol in the gonads, however, continuously rises to a maximum with maturation. That present in the liver and "mesenteric" fat disappears at a far slower rate than do the fatty acids of these tissues, while the percentage in the muscle remains approximately constant throughout.

4. Because, with tissues changing so rapidly in weight, the percentage values give no idea of the absolute changes involved, an attempt has been made to interpret the data along these lines. The probability of the assumptions necessary for this purpose is discussed. The balance-sheet so constructed shows that the loss of fatty acid from the time when the maximum values obtain to the time of maturation are: liver $0.25 \mathrm{~g}$., "mesentery" $2.65 \mathrm{~g}$., muscle $3.76 \mathrm{~g}$. Meanwhile the gonads have gained $0.98 \mathrm{~g}$. The significance of these various changes is discussed.

5. It shows further that, in the last stages of maturation at least, the fish is synthesising cholesterol. 
6. The degree of unsaturation of the fatty acids of the ovaries and testes rises steadily to a maximum before the fish spawns, when the iodine value has risen from 137 to 200 . The iodine values of the acids of the other tissues have however remained constant, the values being for liver 128, mesentery 108 , muscle 118. The possible significance of the finding is discussed.

\section{REFERENCES.}

Bruce (1924). Biochem. J. 18, 469.

Johnstone (1915). 23rd Ann. Rep. Lancashire Sea Fish. Lab. 154.

- (1918). 26th Ann. Rep. Lancashire Sea Fish. Lab. 13.

(1919). 27th Ann. Rep. Lancashire Sea Fish. Lab. 36.

- (1920). 28th Ann. Rep. Lancashire Sea Fish. Lab. 16.

Lea (1910). Cons. Int. Expl. Mer., Public de Circ., No. 53, 7.

Milroy (1906). 24th Ann. Rep. Fishery Bd. for Scotland, Pt. III, 83. (1907). 25th Ann. Rep. Fishery Bd. for Scotland, Pt. III, 197. (1908). Biochem. J. 3, 366.

Rosenmund and Kuhnhenn (1923). Z. Untersuch. Nahr. Genussm. 46, 154.

Saby (1932). 40th Ann. Rep. Lancashire Sea Fish. Lab. 139. 